\title{
KOMPETENSI PEDAGOGIK GURU DALAM PENERAPAN PEMBELAJARAN TEMATIK SECARA DARING DI SEKOLAH DASAR
}

Ika Rakhmawati Suntoro Sitti

Universitas Muhammadiyah Purwekerto, Purwekerto, Indonesia

ikarakhmawati076@gmail.com

\begin{abstract}
Abstrak
Penelitian ini membahas mengenai kompetensi pedagogik guru dalam penerapan pembelajaran daring di sekolah dasar. Dalam penelitian ini bertujuan untuk mendeskripsikan kompetensi pedagogik guru dalam penerapan pembelajaran secara daring di sekolah dasar dan mendekripsikan faktor penghambat dan pendorong pembelajaran tematik secara daring. Penelitian ini menggunakan penelitian deskripstif kualitatif. Subjek penelitian ini mencakup kepala sekolah, guru, dan siswa. Teknik pengumpulan data menggunakan wawancara, angket, dan dokumentasi. Uji keabsahan data dalam penelitian ini menggunakan triangulasi sumber dan triangulasi teknik. Teknik analisis data dilakukan dengan melakukan pengumpulan data, reduksi data, penyajian data, dan menarik kesimpulan. Hasil penelitian ini bahwa kompetensi pedagogik guru terhadap pembelajaran tematik secara daring di sekolah dasarsudah cukup baik. Guru dapat memahami karakteristik peserta didik, mampu menguasai teori belajar dan prinsi-prinsip pembelajaran yang mendidik, melaksanakan pengembangan kurikulum, melaksanakan kegaiatan pembelajaran yang mendidik, melakukan pengembangan potensi peserta didik dan melaksanakan penilaian dan evaluasi. Faktor penghambat guru dalam melaksanakan kegiatan pembelajaran tematik secara online di sekolah dasar diantaranya yaitu jaringan internet yang kurang memadai di daerah tempat tinggal masing-masing peserta didik, tidak semua peserta didik memiliki HP, sehingga menghambat guru dalam melaksanakan kegaitan pembelajran tematik secara daring, dan faktor lingkungan sosial (keluarga). Faktor pendukung guru terhadap pembelajaran tematik secara daring di Sekolah dasar yaitu tersedianya sarana dan prasarana yang memadai seperti setiap guru memiliki gawai untuk mempermudah pembelajaran, buku, modul atau LKS, sehingga memudahkan guru dalam melaksanakan kegaitan pembelajaran tematik secara draing selain menggunakan video pembelajaran.
\end{abstract}

Kata Kunci: Kompetensi Pedagogik Guru, Pembelajaran Tematik, Daring

Published by:

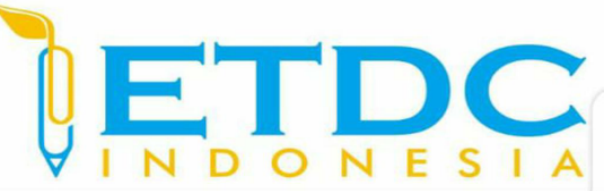

Copyright (C) 2021 The Author (s)

This article is licensed under CC BY 4.0 License

(cc) $\mathrm{BY}$ 


\section{PENGARUH MODEL PROBLEM BASED LEARNING BERBASIS ONLINE TERHADAP HASIL BELAJAR SISWA PADA KONSEP VIRUS}

\section{Pendahuluan}

Pendidikan tidak memandang antar golongan si kaya dan si miskin. Oleh karena itu setiap manusia diharapkan menjadi warga negara yang baik, memiliki sikap serta penuh tanggungjawab yang besar. Muhibbin Syah (2010:10) berpendapat bahwa "Pendidikan adalah mendidik yang artinya memelihara dan memberikan suatu pelatihan melalui pengajaran mengenai akhlak dan kepribadian seseorang untuk mencapai tujuan yang ingin dicapai. Salah satu komponen pendidikan di Indonesia, dimana guru harus mempunyai suatu kompetensi yang wajib dimiliki oleh seorang guru dalam melakukan kegiatan proses pembelajaran.

Guru juga mempunyai peranan penting dalam mendidik anak didiknya seperti halnya dalam melatih, membimbing, mengarahkan dan mengayomi peserta didik. Oleh karena itu guru terutama guru Sekolah Dasar mempunyai peranan yang penting dan aktif dalam proses pembelajaran berlangsung. Guru harus mempunyai keempat kompetensi dalam proses belajar mengajar diantaranya kompetensi pedagogik, kompetensi sosial, kompetensi kepribadian dan kompetensi profesional. Hal ini terctera dalam Undang- Undang No. 14 Tahun 2005 pasal 10 ayat 1 .

Guru juga mampu menguasai materi pelajaran dengan baik agar siswa mampu menerima dan memahami suatu pelajaran dengan baik. Sehingga guru harus berkolaborasi dengan keterampilan, kemampuan dalam mengajar dikelas. Hal ini berkaitan dengan kompetensi pedagogik seorang guru yang dijelaskan (Rusnawati, 2015) bahwa kompetensi pedagogik adalah suatu kemampuan,keterampilan seorang guru dalam mengelola, mengevaluasi hasil belajar pada pembelajaran berlangsung.

Pembelajran Tematik adalah pembelajaran yang yang mengaitkan antara pelajaran satu dengan materi yang lain yang melibatkan siswa dengan pengalaman dan lingkungan sekitar. Pembelajaran tematik merupakan pembelajaran yang menciptakan pembelajaran terpadu dengan melibatkan seorang siswa. Agar siswa mampu berfikir kreatif, dapat menyelesaikan permasalahan yang ada pada kebutuhan siswa serta pembelajarn tematik juga dimaknai dengan mengaitkan beberapa mata pelajaran yang dirancanga dengan berbagai sub tema menurut (Wahyuni et al., 2016) Pembelajaran Tematik merupakan pembelajaran yang harus berfikir kreatif terhadap siswa. Dengan melalui pembelajaran tematik ini sisiwa dapat terlibat langsung dalam pengalaman dkehidupan yang ada dilingkungan sekitar. Pembelajaran tematik pula guru 
harus dituntut untuk menguasai berbgaai aspek dan bidang dalam pelajaran. Guru juga ditunut dalam melakukan pembelajaran tematik dengan kemampuan keterampilan agar siswa mampu mamahami materi yang disampaikan.

Berdasarkan hasil wawancara yang telah dilakukan di Sekolah Dasar Negeri 1 Pepedan dengan wawancara salah satu Guru bahwa yang awalnya proses pembelajaran deilakukan secara tatap muka sekarang beralih ke pembelajaran daring selama pandemi covid 19. Sekolah Dasar Negeri 1 Pepedan saat ini melaksanakan dan menerapkan pembelajaran daring. Pembelajaran daring adalah pembelajaran yang diakses melalui jaringan internet yang dikaukan secara jarak jauh tanpa berinteraksi secara langsung dengan peserta didik. Dengan melalui pembelajaran daring guru dituntut mampu mengaplikasikan suatu teknologi. Guru memberikan tugas atau materi selama proses pembelajaran daring menggunakan media sebagai bahan ajar yang digunakan yaitu video pembelajaran melalui aplikasi teknologi seperti WhatSAap Group. Sekolah Dasar Negeri 1 Pepedan sekarang menggunakan WhatSAap Group dalam melakukan proses kegiatan belajar mengajar untuk menunjang pembelajaran daring. Pada kenyataannya masih ada beberapa guru yang kesulitan atau kurang untuk mengaplikasikan suatu teknologi dalam pembelajran daring dikarenakan pembelajaran daring ini termasuk pembelajaran yang baru.

Pembelajaran tematik menurut (Syaifuddin, 2017) bahwa adalah seorang guru dapat memahami suatu konsep pembelajaran tematik yang akan dilaksanakan seperti pengelolaan pembelajaran tematik yaitu perencanaan, pelaksanaan, dan evaluasi yang harus guru dapat dipahami dan diperhatikan. Pembelajaran tematik merupakan salah satu pola pembelajaran terpadu yang mengaitkan tema dalam mata pelajaran sehingga dapat memberikan pengalaman siswa yang bermakna. Sedangkan pembelajaran terpadu diartikan sebagai pembelajaran yang menghubungkan beberapa ide, konsep, pengetahuan, sikap, dan sebagainya dalam suatu mata pelajaran Pemendikbud No. 57, 2014. Sedangkan (Wahyuni et al., 2016) berpendapat bahwa pembelajaran tematik merupak suatu cara pembelajaran yang memberikan suatu pengalaman kepada peserta didik dengan mengaitkan beberapa mata pelajaran termasuk sub tema, serta melibatkan siswa untuk berpartisipasi aktif dalam pross pembelajaran berlangsung.

Menurut Departemen Pendidikan Nasional (Depdiknas, 2019: 22) menyatakan bahwa pembeajaran tematik adalah sebagai suatu model proses, yanag memiliki karakteristik hal ini dapat diuraiakan sebagi berikut: 1) Berpusat pada peserta didik, 2) Memberikan pengalaman langsung, 3) Pemisahan antar mata pelajaran tidak begitu kelihatan, 4) Konsep dari beberapa mata pelajaran disajikan dalam satu pelajaran, 4) Bersifat luwes atau felksibel, 5) Hasil pembelajaran dapat berkembang sesuai dengan kebutuhan minta dan kebutuhan peserta didik. 
Perkembangan pembelajaran tematik ini tentu akan membutuhkan kemampuan, bakat dan minat seorang siswa.

Pembelajaran daring adalah pembelajaran yang dilakukan secara jarak jauh tanpa berinteraksi secara langsung dengan penunjang seperti handphone, laptop, dan komputer salah satu bentuk pembelajaran yang telah dimodifikasi ke teknologi komunikasi informatsi untu diterapkan ke dunai pendidikan. E-learning juga dapat diartikan sebagai model pembelajaran teknologi guna untuk melakukan pembelajaran ke dalam dunia pendidikan ke dunia maya tanpa bertatap langsung deengan seseorang. Hanya berinteraksi dengan jarak jauh (Putria et al., 2020). Sedangkan menurut (Sadikin \& Hamidah, 2020) juga berpendapat bahwa pembelajaran daring merupakan pembelajaran yang menggunakan jaringan internet aksesbilitas, konektivitas, flesibilitas, dan kemampuan untuk memunculkan berbagai jenis interaksi pembelajaran. Oleh karena itu pembelajaran daring merupakan yang mampu mempertemukan guru dengan peserta didik, dan dosen dengan mahasiswa untuk melaksanakan kegiatan interaksi dan komunikasi melalui berbagai jenis internet. Berdasarkan pendapat diatas bahwa pembelajaran daring adalah pembelajaran yang dilakukan dengan jarak jauh tanpa berinterkasi secara langsung kepada seseorang dengan menggunakan jaringan internet ang diakses melalui web broser.

\section{Metode Penelitian}

Penelitain Kualitatif merupakan sebuah data yang berbentuk deskriftif atau narasi, yang berupa suatu tulisan atau kata-kata secara lisan maupun tulisan yang berkaitan dengan perilaku manusia yang diamati oleh manusia serta menafsirkan data yang ada di lokasi seperti situasi yang dialami (Wibowo \& Maqfirotun, 2016). Sedangkan (Prasanti, 2018) menyatakan bahwa penelitian kualitatif adalah penelitan kualitatif yang digunakan untuk melakukana suatu peneliti yang bersifat alamiah yang dimana peneliti sebagai intstrumen kunci. Penelitian deskriptif merupakan penelitian yang menggali suatu informasi atau sumber pada suatu objek serta keadaan, kondisi yang ada dilapangan. Penelitian ini bertujuan untuk mendeskripsikan suatu permasalahan yang ada di lapangan, kondisi, situasi maupun keadaan yang terkait tentang kompetensi pedagogik guru di SD N 1 Pepedan pada mata pembelajaran tematik.

Teknik Pengumpulan data dalam penelitian ini menggunakan teknik observasi, wawancaara, dan dokumentasi. Peneliti menggunakan teknik tringulai sumber dan tringulasi teknik untuk keabsahan data. Penelitian ini menggunakan analisis data model Miles dan Huberman yang terdapat 3 tahap dalam analisis data yaitu data reduction (reduksi data), data display (penyajian data), dan conclusion drawing/verification (penarikan kesimpulan). Uji Keabsahan data dapat dilakukan dengan membuktikan mengenai penelitian yang dilakukan 
benar-benar merupakan penelitian ilmiah sekaligus untuk menguji data yang telah diperoleh. Untuk mengecek keabsahan data peneliti menggunakan triangulasi teknik dan triangulasi sumber.

\section{Hasil dan Pembahasan}

Pengambilan data di SD N 1 Pepedan dimulai pada bulan Febuari-Maret. Data mengenai kompetensi pedagogik guru dalam penerapan pembelajaran tematik secara daring di Sekolah Dasar yang diperoleh melalui wawancara, observasi, dan dokumentasi. Wawancara dilakukan pada guru kelas $\mathrm{V}$ yang diperkuat oleh kepala sekolah, dan didukung oleh peserta didik kelas $\mathrm{V}$.

\subsection{Hasil}

a. Kompetensi Pedagogik Guru dalam Penerapan Pembelajaran Tematik secara Daring di Sekolah Dasar

1. Menguasai karakter peserta didik. Untuk menguasai karakter peserta didik, guru dapat mengetahui dengan melihat kedisplinan peserta didik, kejujuran peserta didik, serta tanggungjawab peserta didik melalui absensi ataupun tugas-tugas yang diberikan oleh gurunya tersebut secara online melalui Wa group, memastikan peserta didik mendapatkan kesempatan belajar dan berpartisipasi aktif dalam belajar, guru memberikan kesempatan kepada peserta didik melalui Wa Group, dan guru mengulang kembali materi pembelajaran dan menjelaskan alur pembelajaran secara jelas. Berdasarkan hasil wawancara yang dilakukan, menjelaskan terkait karakteristik yang dimiliki peserta didik kelas V. Peserta didik kelas V memiliki karakter yang berbedabeda antara peserta didik dengan peserta didik yang lainnya.

2. Menguasai teori belajar dan prinsip-prinsip pembelajaran yang mendidik. Untuk menguasai kompetensi tersebut guru dapat memberikan informasi atau materi pembelajaran lewat WhAatsap Group, seperti menggunakan video pembelajaran, merencanakan pembelajaran yang saling terkait, guru juga selalu memahami tingkat pemahaman peserta didik, guru dapat memperhatikan respon peserta didik yang belum memahami materi pembelajaran lewat online. Selain itu juga guru memberikan modul kepada siswa untuk dipelajari dengan cara memberikan arahan cara melaksanakan tugas siswa dengan jelas. Guru juga dapat memberikan pembelajaran yang bersifat kognitif afektif dan psikomotor.

3. Pengembangan kurikulum. Guru mampu mengembangkan kurikulum. Pengembangan 
kurikulum ini dapat dilakukan dengan cara merancang RPP yang sesuai dengan silanbus, Program Tahunan, Program semester, Program harian yang sudah di tuangkan dalam tabel, dengan menyesuaikan kondisi lingkungan sekolah yang ada serta mengaitkan materi pelajaran dengan pengalaman siswa dalam kehidupan sehari-hari dan menyusun materi pelajaran sesuai dengan tujuan pembelajaran.

4. Pengembangan peserta didik. Guru memberikan potensi peserta didik dengan berbagai cara atau strategi yan dilakukan oleh guru seperti memberikan tugas modul.

5. Komunikasi dengan peserta didik. Dalam komumikasi dengan peserta didik, guru dalam melaksanakan pembelajaran guru menggunakan "media video pembelajaran, modul tematik, dan kelompok belajar yang memperhatikan prokes covid 19.

6. Penilaian dan evaluasi. Guru menganalisis hasil evaluasi dan penilaian belajar siswa untuk menjadikan suatu patokan dalam melaksanakan kegiatan pembelajaran selanjutnya. Dalam melakukan penilaian dan evaluasi guru kelas V menggunakan tiga penialian, yaitu penilaian sikap, penilaian pengetahuan, dan penilaian keterampilan. Untuk menilai sikap dari peserta didik guru melakukan dengan cara kesesuaian tugastugas yang telah diberikan, ketepatan pada waktu mengumpulkan tugas, dan mengamati kebenaran cara menyelesaikan tugasnya. pada penilaian keterampilan dengan menggunakan produk atau praktek suatu keterampilan. Sedangkan teknik penilaian pengetahuan guru menggunakan teknik teks tertulis.

7. Kegiatan pembelajaran yang mendidik. Pembelajaran yang mendidik yang diakukan oleh guru kelas V melaksanakan kegiatan pembelajaran sesuai dengan rancangan yang telah dibuat. Guru memberikan materi pembelajaran dan mengembangkan dengan menyesuaikan kondisi peserta didik.

\section{b. Faktor Penghambat Guru dalam melaksanakan kegiatan Pembelajaran Tematik Secara Daring di Sekolah Dasar}

Guru dapat melaksanakan kegiatan pembelajaran ada beberapa hambatan-hambatan yang dialami pada saat mengajar. Hambatan-hambatan itu muncul dari berbagai faktor yaitu faktor internal dan faktor eksternal. Berikut ini gambaran temuan penelitian faktor penghambat guru dalam melaksanakan kegiatan pembelajaran tematik di kelas V SD N 1 Pepedan dilihat dari faktor internal dan faktor eksternal.

Faktor internal penghambat guru dalam melaksanakn kegiatan pembelajaran tematik yang pertama yaitu berkaitan dengan motivasi dalam belajar peserta didik. Berdasarkan hasil wawancara dengan guru kelas $\mathrm{V}$, bahwa peserta didik kurang mampu untuk belajar secara 
daring dengan kendala jaringan internet.

Selain faktor internal, terdapat hambatan yang lain yaitu dari faktor eksternal yaitu kurikulum sekolah. Dengan adanya perubahan kurikulum 2013 guru merasa kesulitan dalam hal penialian dalam melaksanakan kegaiatan pembelajaran tematik.

Hambatan dari faktor eksternal lainya yaitu lingkungan sosial peserta didik. Lingkungan sosial peserta didik yang kurang mendukung dalam pembelajaran salah satunya adalah lingkungan keluarga. Sebagian orang tua kurang memperhatikan proses belajar peserta didik secara daring. Orang tua kurang memperhatikan peserta didik dalam belajar banyak orang tua yang harus bekerja dan banyak orang tua yang tidak mengerti dengan materi pelajaran sehingga orang tua kurang memperhatikan. Keberhasilan peserta didik dalam proses belajar apabila orang tua yang selalu mengawasi dan memperhatikan anak didiknya pada saat belajar.

Berdasarkan wawancara dengan kepala sekolah, pernyataan dari guru kelas V sama dengan yang disampaikan oleh kepala sekolah. Berikut pernyataan kepala sekolah" Faktor lingkungan keluarga tentu ada, karena ada sebagain orang tua yang bekerja diluar pulangnya samapai sore, anak ikut dengan saudaranya sehingga anak kurang mendapatkan perhatian.”(W.KS). Hal ini juga disampaikan oleh 3 peserta didik kelas V, bahwa mereka belajar sendiri, bahkan belajar bersama temannya dirumah.

\section{c. Faktor pendukung guru dalam melaksanakan kegaitan pembelajaran tematik secara daring si Sekolah Dasar}

Faktor pendukung guru dalam melaksanakan kegaiatan pembelajaran tematik seara daring yaitu faktor internal dan faktor eksternal. Berdasarkan hasil wawancara dengan informan, faktor internal pendukung yaitu ciri khas atau karakteristik peserta didik. Ciri karakteristik peserta didik ini berkaitan dengan minat belajar peserta didik. Faktor dari eksternal yang lainnya yaitu sarana dan prasarana yang tersedia di SD N 1 Pepedan sudah cukup memadai. Fasilitas yang tersedia adalah ruang perpustakaan. Namun dengan adanya kondisi pandemi covid 19 guru melaksanakan kegiatan pembelajaran secara daring.

\subsection{Pembahasan}

Dalam pembahasan ini tentang kompetensi pedagogik guru dalam penerapan pembelajaran tematik serta faktor pendukung dan penghambat guru dalam pembelajaran tematik.

\section{a. Kompetensi Pedagogik Guru dalam Penerapan Pembelajaran Tematik secara daring di SD N 1 Pepedan}

Kompetensi pedagogik yang pertama yang harus dikuasi oleh guru yaitu memahami 
karakteristik peserta didik. Guru kelas V mengamati dan menganalisis keterampilan, minat, dan sikap peserta didik. Berdasarkan pengamatan guru kelas V karakteristik siswa berbeda-beda. Dalam kondisi pandemi covid 19 ini guru mengamati dan menganalisis siswa dengan cara melihat dari tugas-tugas diberikan oleh guru dalam proses pembelajaran (Janawi, 2019). Selain itu, dalam memahami karakter peserta didik guru kelas $\mathrm{V}$ dapat memastikan semua peserta didik mendapatkan kesempatan yang sama, berpartisipasi aktif dalam proses pembelajaran secara daring. Kesempatan yang sama dapat melalui dengan guru memberikan materi pelajaran kepada siswa, apabila ada siswa yang kurang paham dengan materi pelajaran yang diberikan guru siswa dapat bertanya melalui Wa group (Janawi, 2019).

Menurut (Hardianto, 2012) salah satu indikator dalam memahami karakteristik peseta didik dalam proses kegiatan pembelajaran tematik secara daring, selain melihat dari tugas-tugas yang diberikan guru juga menganalisis dengan cara melihat motivasi yang tinggi, dan pengalaman peserta didik dalam menggunakan teknologi dalam proses pembelajaran daring.

Kompetensi pedagogik yang kedua yaitu guru mampu menguasai teori belajar dan prinsip-prinsip pembelajaran yang mendidik. Guru kelas V memberikan pembelajaran dengan menggunakan video pembelajaran yang berkaitan dengan pengalaman kehidupan siswa seharihari, selain itu juga guru memberikan motivasi dan dorongan kepada peserta didik serta orang tua untuk mengawasi dan membimbing selama proses pembelajaran daring (Anis, 2019).

Indikator yang lainnya yaitu guru dapat merencanakan pembelajaran yang mendidik. Guru melaksanakan kegiatan proses pembelajaran tematik secara online sudah sesuai dengan rancangan yang telah dibuat sebelumnya. Guru kelas V memberikan materi pelajaran sudah saling terkait dengan berbagai pengalaman siswa dalam kehidupan sehari-hari sesuai dengan rancangan dan tujuan pembelajaran.(Anis, 2019).

Kompetensi yang ketiga yaitu pengembangan kurikulum. Pengembangan kurikul dilakukan dengan merancang RPP yang sesuai dengan silabus, program tahunan, program semester, program harian. Dan mengaitkan materi dengan pengalaman kehidupan siswa seharihari. Menurut (Nasution, 2017) perencanaan pembelajaran adalah suatu proses pembelajaran untuk menentukan suatu tujuan pembelajaran, startegi pembelajaran, dan teknik pembelajaran untuk mencapai hasil yang dicapai. Disamping itu juga guru harus membuat program tahunan, menurut (Samudra, 2020) program tahuanan adalah suatu rencana penetapan alokasi waktu selama satu tahun ajaran pembelajaran untuk mencapai tujuan kompetensi.

Kompetensi yang keempat yaitu pengembangan potensi peserta didik. Pengembangan potensi peserta didik yang dilakukan oleh guru dengan memberikan motivasi dorongan kepada peserta didik serta orang tua untuk giat membimbing, mengawasi, dan memperhatikan proses 
kegiatan pembelajaran tematik secara daring.

Kompetensi yang kelima yaitu komunikasi dengan peserta didik. Komunikasi guru kelas $\mathrm{V}$ dengan peserta didik guru menggunakan video pembelajaran dan Wa Group pada saat melaksanakan pembelajaran secara daring agar proses pembelajran berjalan dengaan lancar (Shadiqien, 2020). Guru menggunakan pertayaan melalui Wa Group apabila ada siswa yang kurang paham.

Kompetensi yang keenam yaitu penilaian dan evaluasi. Guru kelas V melakukan penilaian dan evaluasi menggunakan 3 jenis yaitu penilaian sikap, keterampilan, dan pengetahuan. Untuk menilaian sikap menggunakan tugas-tugas yang diberikan tepat waktu atau tidak dalam mengerjakan tugas. Penilaian keterampilan dengan suatu proyek yang dibuat oleh siswa, sedangkan untuk pengetahuan saya menggunakan teks tertulis dengan memberikan tugas atau materi berupa modul untuk dipelajari melalui Wa Group.

Kompetensi yang ke tujuh yaitu pembelajaran yang mendidik. Guru memberikan materi pembelajaran sesuai dengan rancangan yang telah dibuat sebelumnya dan menyesuaikan kondisi peserta didik. Guru melakukan proses kegiatan pembelajaran secara daring dengan membuat materi atau video pembelajaran secara menarik, dan sekreatif mungkin.

\section{b. Faktor Penghambat Guru dalam Pelaksanaan Pembelajaran Tematik secara daring di Sekolah Dasar}

Faktor penghambat internal dan ekternal adalah segala sesuatu yang menghalangi suatu kegiatan proses pembelajaran. Faktor internal adalah pembuatan rancangan pembelajaran yang tidak sendiri-sendiri, karena pembelajaran tematik sudah menjadi beberapa sub tema sehingga guru dalam memberikan materi pembelajaran harus mengaitkan dengan kehidupan sehari-hari peserta didik (Sobur, 2016). Selain itu juga sarana dan prasarana yang kurang memadai seperti, jaringan internet yang tidak stabil saat guru memberikan materi pelajaran baik berupa video, penjelasan melalui Wa Group. (Sadikin \& Hamidah, 2020).

Faktor eksternal penghambat proses pelaksanaan pembelajaran yaitu Kurikulum 2013. Dengan adanya perubahan kurikulum, guru kesulitan dalam penilaian peserta didik, menentukan bahan ajar, serta kendala waktu dan kondisi pada saat proses kegiatan pembelajaran daring. Faktor eksternal lainnya yaitu dari lingkungan keluarga dimana orang tua kurang perhatian terhadap peserta didik, dikarenakan sebagian wali peserta didik tidak ada dirumah harus bekerja di luar rumah. Peserta didik harus belajar di rumah bersama saudara atau temannya yang kurang memperhatikannya. Faktor lingkungan sosial juga terdapat pengaruh negatif dan pengaruh positif terhadap peserta didik.(Faizah, S., 2017). 


\section{c. Faktor pendukung Guru dalam Melaksanakan Pembelajaran Tematik}

Ada faktor internal dan faktor eksternal yang mempengaruhi dalam melaksanakan pembelajaran tematik. Faktor internal pendukung guru dalam melaksanakan kegiatan pembelajaran tematik yaitu karakteristik peserta didik. Menurut (Faizah, S., 2017) Guru memahami karakteristik peserta didik dengan menganalisis minat, kematangan, kesiapan peserta didik dalam mengikuti proses kegiatan pembelajaran tematik berlangsung. Minat, kematangan, dan kesiapan belajar tinggi yang dimiliki peserta didik guru kelas $\mathrm{V}$ sangat mendukung dalam proses kegaiatan pembelajaran. Minat merupakan salah satu menjadi faktor pendukung dalm proses belajar tematik. Kematangan dan kesiapan juga menjadi faktor pendukung dalam proes kegiatan belajar tematik peserta didik.

Faktor internal lainnya yaitu sarana dan prasarana. Menurut (Jannah \& Sontani, 2018) Sarana merupakan bahan untuk dijadikan suatu model untuk kegaiatan ataupun aktivitas. Sedangkan prasana adalah segala sesuatu yang mencakup semuanya guna untuk menunjang kegiatan atau aktivitas. Guru kelas V melaksanakan kegiatan pembelajaran dengan memberikan modul yang telah dibuat sesuai dengan rancangan yang ada. Modul dijadikan sebagai bahan belajar peserta didik.

Ada faktor eksternal yaitu jaringan internet yang kurang memadai untuk melakukan pembelajaran daring. Banyak siswa dan orang tua yang mengeluh karena sinyalnya tidak stabil. Dan akhirnya siswa merasa bosan dan jenuh belajar di rumah karena harus terpacu dengan internet dan tidak ada berinteraksi secara langsung dengan guru. Selanjutnya faktor dari lingkungan sosial yang berasal dari keluarga. Sebagaian siswa yang harus belajar sendiri dirumah tanpa didampingi oleh orang tua. Karena orang tua harus bekerja di luar pulang sampai sore. Jadi peserta didik kurang mendapatkan perhatian dan bimbingan dari orang tua.

\section{Kesimpulan}

Kompetensi pedagogik guru dalam penerapan pembelajaran tematik secara daring di Sekolah Dasar sebagai berikut.

a. Kompetensi Pedagogik Guru dalam Penerapan Pembelajaran Tematik secara Daring di Sekolah Dasar.

Kompetensi Pedagogik guru terhadap penerapan pembelajaran tematik secara daring dilaksanakan dengan baik. Kompetensi pedagogik guru dalam penerapan pembelajaran tematik pada kondisi covid-19 guru harus mempunyai 7 kompetensi di SD N 1 Pepedan sudah cukup baik dalam melaksanakan kegiatan pembelajaran tematik secara daring. Guru memahami 
karakteristik peserta didik dengan cara melihat dari rekapan tugas peserta didik, teori dan prinsip-prinsip dalam pembelajaran juga guru di SD N 1 Pepedan sudah melaksanakan dengan baik.

b. Faktor penghambat dan pendukung Guru dalam melaksanakan Kegiatan Pembelajaran

Tematik secara daring di Sekolah Dasar

Faktor penghambat dalam pembelajaran tematik secara daring diantaranya, sebagaian peserta didik yang tidak memiliki Handphone, jaringan internet yang kurang memadai di daerah tempat tinggal masing-masing peserta didik dan kuranggnya pengawasan dari keluarga. Faktor pendukung dalam pembelajaran tematik secara daring yaitu tersedia fasilitas sarana dan prasarana seperti internet untuk menunjang guru dalam melaksanakan kegiatan pembelajaran tematik secara daring, sehingga guru bisa mengembangkan materi-materi yang akan diajarkan, adanya buku modul, serta materi dari video pembelajaran yang dapat siswa pelajari dirumah.

\section{DAFTAR PUSTAKA}

Asim, M., \& Lobo, N. J. (2018). The Application of My Pedagogic Creed from Experiential Learning Perspective. Journal of Education and Educational Development, 5(2), 107-125. https://login.proxy006.nclive.org/login?url=http://search.ebscohost.com/login.aspx?direc $\underline{\mathrm{t}=\text { true } \& \mathrm{db}=\text { eric } \& \mathrm{AN}=\mathrm{EJ} 1200332 \& \text { site }=\text { ehost-live \&scope }=\text { site }}$

Assingkily, M. S., \& Br. Barus, U. S. (2019). Pembelajaran Tematik Bagi Anak Usia Dasar(Metodologi Dalam Islam). Nizhamiyah, 9(2), 14-29. https://doi.org/10.30821/niz.v9i2.548

Mukhtar, A., \& MD, L. (2020). Pengaruh Kompetensi Guru Terhadap Kinerja Guru Dan Prestasi Belajar Siswa Di Kota Makassar. Idaarah: Jurnal Manajemen Pendidikan, 4(1), 1. https://doi.org/10.24252/idaarah.v4i1.13899

Prasanti, D. (2018). Penggunaan Media Komunikasi Bagi Remaja Perempuan Dalam Pencarian Informasi Kesehatan. LONTAR: Jurnal Ilmu Komunikasi, 6(1), 13-21. https://doi.org/10.30656/lontar.v6i1.645

Putria, H., Maula, L. H., \& Uswatun, D. A. (2020). Analisis Proses Pembelajaran dalam Jaringan (DARING) Masa Pandemi Covid- 19 Pada Guru Sekolah Dasar. Jurnal Basicedu, 4(4), 861-870. https://doi.org/10.31004/basicedu.v4i4.460

Sadikin, A., \& Hamidah, A. (2020). Pembelajaran Daring di Tengah Wabah Covid-19. Biodik, 6(2), 109-119. https://doi.org/10.22437/bio.v6i2.9759

Syahrial, S., Asrial, A., Kurniawan, D. A., Chan, F., Pratama, R. A., Nugrogo, P., \& Septiasari, R. (2019). The impact of etnocontructivism in social affairs on pedagogic competencies. International Journal of Evaluation and Research in Education, 8(3), 409-416. https://doi.org/10.11591/ijere.v8i3.20242 
Syaifuddin, M. (2017). Implementasi Pembelajaran Tematik di Kelas 2 SD Negeri Demangan Yogyakarta. Tadris: Jurnal Keguruan Dan Ilmu Tarbiyah, 2(2), 139. https://doi.org/10.24042/tadris.v2i2.2142

Wahyuni, H. T., Setyosari, P., \& Kuswandi, D. (2016). Implementasi Pembelajaran Tematik $\begin{array}{lllll}\text { Kelas } & 1 & \text { Sd. } & \text { Edcomtech, } & 1(2),\end{array}$ http://journal2.um.ac.id/index.php/edcomtech/article/download/1799/1039 